\title{
LOCAL PUBLIC POLICY AND THE RESIDENTIAL DEVELOPMENT PROCESS:
}

\author{
Edward J. Kaiser† and Shirley F. Weiss $\ddagger$
}

Although local public policies must be legally sound and administratively feasible, they must also adapt to the urban social, economic, and political processes with which they are merged if they are to be effective in influencing those processes. This article considers the nature of one such process, the residential development process by which land is changed from nonurban use to urban residential use and the implications for local public policies. By conceptualizing the development processes and the role of public policy within these processes, we attempt to gain insight into the problem of designing local public policies to guide residential development.

Our approach views the residential process as the cumulative result of a complex of decisions and actions by individuals and groups, each being guided by his own incentives-the household consumer by basic needs and preferences, the developerentrepreneur by the profit motive, the predevelopment landowner by a mixture of pecuniary and personal motives. The approach is also based on the micro-behavioral aspects of the development processes-individual units of property, individual pre-

* The research reported in this paper was financed in part by the Environmental Enginecring Policics and Urban Development Project, Public Health Service Research Grant EF 00407-05, of the Division of Environmental Engineering and Food Protection. The material reported in this paper draws from a larger study and a larger team effort in the area of "Environmental Engineering Policics and Urban Development." The authors acknowledge the major contributions of present and former colleagues who have been actively associated with various stages of the research and who have participated in the Development Decisions Seminar. In particular, the following were intimately involved in the ongoing research while in residence in Chapel Hill as graduate students in the Department of City and Regional Planning and as research assistants or research fellows at the Center for Urban and Regional Studics: Kenneth B. Kenney, Assistant Professor of Planning, University of Tennessee, Knoxville; John E. Smith, Planning Economist, Office of Planning Coordination, State of New York Executive Department, Albany: L. Earl Armiger, Community Planner, Brevard County Planning Department, Titusville, Fla.; Roger C. Steffens, Principal Planner, City Planning Commission, Huntsville, Ala.; and Donald A. Stollenwerk, Chief Community Planner, Lancaster County Planning Commission, Lancaster, Pa.

† B.Arch. 1958, Illinois Institute of Technology; Ph.D. 1966, University of North Carolina. Assistant Professor of Planning, Department of City and Regional Planning, and Research Associate, Institute for Research in Social Science, University of North Carolina at Chapel Hill. Co-author [with S. F. Wciss, J. E. Smith \& K. B. Kenney], Residential Developer Decisions: A Focused View of the Undan Growrt Process (Urban Studies Research Monograph, Institute for Research in Social Science, University of North Carolina, r966); author, Toward a Model of Residential Developer Locational Bchavior, I966 ( unpublished thesis in University of North Carolina Library).

$\ddagger$ A.B. 1942, Rutgers University; M.R.P. I958, University of North Carolina. Associate Research Director, Center for Urban and Regional Studies, Associate Professor of Planning, Department of City and Regional Planning, and Research Associate, Institute for Research in Social Science, University of North Carolina at Chapel Hill. Co-editor and co-author [with F. S. Chapin, Jr.], UnBan Growtr Dynamics in a Regional Cluster of Cities (I962); co-author [with F. S. Chapin, Jr. \& T. G. Donnelly], Factors Influencing Land Development: Evaluation of Inputs for a Forecast Model (ig62); A Probabilistic Model for Restdential Growth (rg64), and SOME INPUt Repinements for $\wedge$ ResiDeNTIAL Model (I965) (Urban Studies Research Monographs, Institute for Research in Social Science, University of North Carolina, in cooperation with the U.S. Bureau of Public Roads, Dep't of Commerce). 
development landowners deciding to sell or to hold property, individual developers purchasing sites and producing individual residential products for sale, and individual households choosing among alternative residential units.

Although the approach in this article is primarily conceptual, it is firmly based on a series of in-depth interviews and other extensive field data concentrating on Greensboro, North Carolina, but including other North Carolina Piedmont cities as well. The empirical approach, relying heavily on tape-recorded interviews, is experimental. It is being tested in other cities of different sizes and different growth characteristics and is being extended to other decision agents in both the development and the redevelopment processes. In addition to our own empirical work at the Center for Urban and Regional Studies, the conceptualizations also draw upon related literature and research done in other areas of the country. Because of this, we feel the basic conceptualizations about public policy merged with the residential processes should have general nationwide applicability to urban areas, although many of the specific findings would require recalibration in applications to specific urban areas due to our primary dependence upon one study area.

Conceptual Overview of the Residential Development Process

Residential development may be seen as land in an urban area passing through a sequence of states over time. Beginning with a unit of land in nonurban use on the periphery of an urban area, one could trace the transition from an initial state of nonurban use through several stages of development to a state of active residential use by a household. A typical chain of states for a unit of land is shown in the top row of figure I. Local public policies for urban residential growth might be conceived as an attempt to control the spatial and temporal probabilities of units of land changing from one state to another.

The evolution of the property through this observable chain of sequences is a result of another process not quite so easily observed. This is the complex set of critical decisions which are made over time by a group of key and supporting decision agents. The key decision agents include the landowner, the developer, and the household. Their decisions are necessary in order for land to evolve through the sequence of states. The relationship of these decisions and decision agents to the sequence of states is illustrated in figure I. For example, at the beginning of the process at the left side of the figure, for land to move into the state of active consideration for residential development, both the developer and the landowner must decide to consider the land for purchase and sale in anticipation of residential development.

Going one step deeper into our conceptual framework, we introduce three sets of decision factors to explain the decisions which in turn explain the evolution of 


\section{FIGURE I}

The Residential Land Development Process: Sequence of States, Kex Decisions, Decision Factors, and Local Public Policies

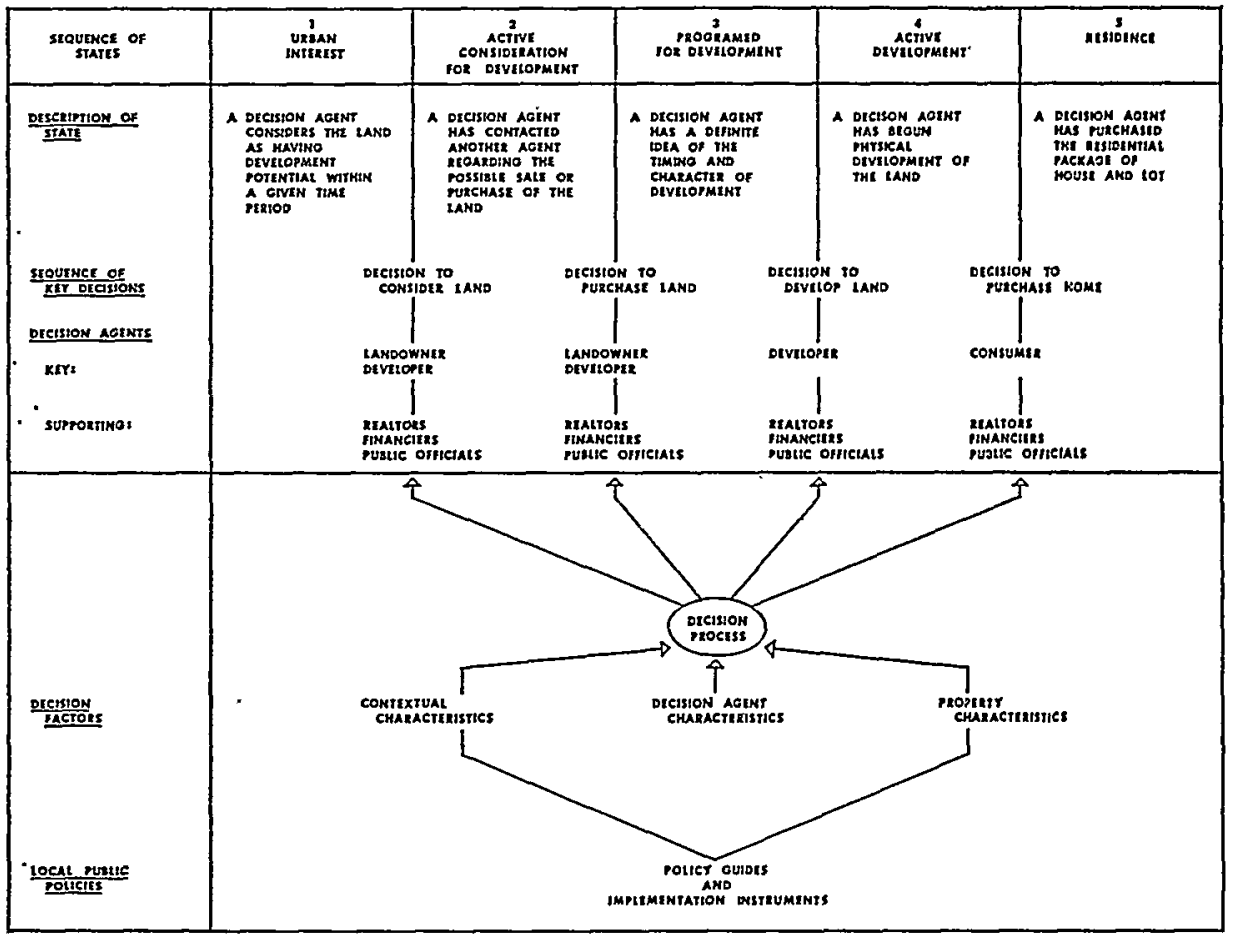

property through the development process. The lower portion of figure I shows the three sets of decision factors: contextual, decision agent, and property characteristics. Each of the sets of factors influences the decision process in a unique way. The contextual factors provide the macro environment for development decisionsnamely, the considerations which limit and determine the overall rate and type of change in the urban community and the general structure of the population of decision agent characteristics and property characteristics. Property characteristics describe the property about which decisions are made. Finally, decision agent characteristics are crucial in explaining important variation in decisional behavior among decision makers in the face of similar contextual and property characteristics.

At this point we can introduce the relationship of local public policy to the conceptualization of the residential process. We see local public policy as an attempt to influence the residential evolution of land by affecting the basic decision factors. As shown in the bottom of figure $I$, the influence of local public policies on the evolution of land is indirect, being channeled through constraining contextual and property characteristics; policy does not affect landowner characteristics directly. 
The important aspects of the public policy are its content, the differentiation of the application of this content to properties over space and time, and finally the expected variation in reactions of the different decision makers to the policy content.

Let us conceptualize an overview of local public policy merged with the residential development process by integrating the relationships discussed above. The evolution of urban property through a sequence of states is the result of a series of decisions. Inputs to each decision process in the sequence consist of three sets of decision factors. The output of the decision process is a determination of whether or not there is to be a change in the state of the property. The influence of local public policy on the outputs of these decision processes and hence on the evolution of property is channeled through the input decision factors. Figure 2 illustrates the relationships between the decisions, the decision factors, and the policy factors to be explored in this paper.

\section{FIGURE 2}

Elements in the Residential Development Process: An Analytical Framework

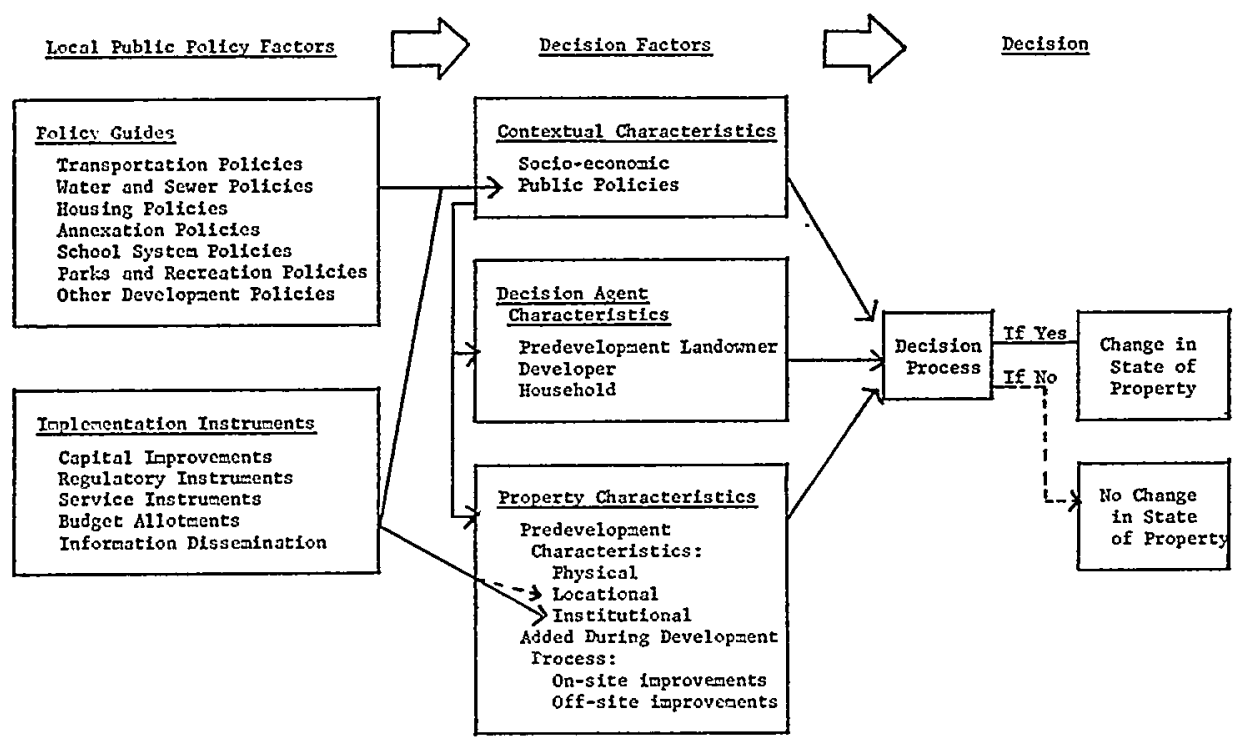

In the following three sections we utilize the above conceptualizations in discussing the decision of the predevelopment landowner to sell or not to sell, the locational decision of the developer-producer to develop a property or to look for another location, and the selection of a residential place by a household consumer.

\section{II}

The Decisions of the Predevelopment Landowner

Land assumes the state of urban interest when a decision agent considers the land as having urban development potential. With the attainment of this state, 
the prevailing use, usually agricultural, begins to share the determination of the value of the land with the potential urban use of the land. The land use thus becomes transitional. ${ }^{1}$ It generates an income stream which, when capitalized, supplements the speculative value of the land based on its potential urban use. Sometimes this transitional nature of the use is obvious-e.g., junk yards and used car lots. But sometimes it is disguised as the old use which is carried on to help tide the landowner over the transitional period when the land is in the state of urban interest, but is not yet under active consideration for development by a developer or the current landowner. Nevertheless, the old use is actually being made increasingly obsolete by the increasing proportion of the value of the property attributable to existing and anticipated land use changes and urban investment all about.

Let us examine the transitional landowner's decision to hold or to sell in order to try to explain why some land in the urban fringe becomes residentially developed and why other land does not. A useful conceptualization of the landowner views him as a

rational individual who attempts to maximize his satisfaction from a given stock of pecuniary and nonpecuniary assets, including the land. Primarily, the landowner's decision to sell or hold the land depends upon his satisfaction from the pecuniary income from the land in the form of current and expected income, relative to income from alternative investments. ${ }^{2}$

The pecuniary aspect of the landowner's decision to sell or to hold the land relates to the net annual holding cost of the land, the costs that would be incurred in shifting to another investment, the opportunity costs of capital, and the time period of the investment. ${ }^{3}$ "Secondarily, the landowner's decision depends upon his relative satisfaction from nonpecuniary income from the land in the form of 'farming as a way of life,' the land as a residence, 'love of the land,' or privacy and status."

It appears that both pecuniary and nonpecuniary motives are too important to be ignored in the explanation of the predevelopment landowner's decision to sell or to hold. Some research stresses the pecuniary and other research suggests the importance of the nonpecuniary. Speculative pecuniary motives were found to be most important in separate studies by Maisel and by Lessinger in California. Maisel tentatively concluded that "the possibilities of capital gains have become the dominant factor influencing ownership of land upon which urban development would be expected in the next decade or two. ... In the past 12 years [1959-1962], almost half of the land held by the earlier owners was sold to those primarily interested

\footnotetext{
${ }^{1}$ See J. Lessinger, The Determinants of Land Use in Rural-Urban Transition Areas: A Case Study of Santa Clara County, California, 1957 (unpublished thesis in University of California Library).

${ }^{2}$ See J. E. Smith, Toward a Theory of Landowner Behavior on the Urban Periphery, 1966, at 53 (unpublished thesis in University of North Carolina Library).

${ }^{3} l d$. at $32-46$.

${ }^{4} 1 d$. at $53-54$.
} 
in capital gains." Lessinger also found that although the fruitgrowers' willingness to hold the land in transitional agricultural use "could theoretically result either from expectation of speculative rates of return or from intangible returns . . [ [i] the actual case area under study, speculative interests predominate." ${ }^{\text {"6 }}$ But in support of the importance of nonpecuniary motives, Kenney found that "while price and profit motivations loomed large as both primary and secondary factors affecting the decision to sell, personal circumstances and land oriented factors (property characteristics) play key roles in these decisions."7 Kenney's conclusion is reinforced by Bahl, who commented on why intervening land in his study area was passed over: "Information which could be gained from the owner of one of the large intervening tracts of land and from many secondary sources suggests that the land in question was withheld, at least partially, for personal reasons."8

The following equation, formulated by Smith, is a concise statement of the factors entering into the conceptualized decision of the landowner to hold or to sell : ${ }^{9}$

$$
P V=\sum_{t=I}^{n} \frac{\left(a t^{p}+a_{t}^{n p}\right)-\left(e_{t}^{p}+e_{t}^{n p}\right)}{(I+r)^{t}}+\frac{E V-C}{(I+r)^{n}}
$$

PV-the present value of the land, where:

$a_{t}{ }^{p}$ - the annual pecuniary income from the property in year $t$

$a_{t}{ }^{n}$ - the annual nonpecuniary income from the property in year $t$

$\mathrm{e}_{\mathrm{t}}^{\mathrm{p}}$ - the annual pecuniary expense on the property in the year $t$

$e_{t}{ }^{n}$ - the annual nonpecuniary expense on the property in the year $t$

$\mathrm{r}$-the opportunity cost of capital, i.e., the rate of return foregone on a possible alternative investment

$\mathrm{n}$-the number of years that the land would be held

EV-the expected value or market price in the year of sale, $n$

C-the transfer and transaction costs associated with a shift in investment

Upon estimation of the present value, PV, the landowner follows the traditional decision rule: sell the land if his (landowner's) estimated present value falls below the present market price of the land.

Factors which tend to encourage the sale of the land are those which lower the present value estimate or raise the current market price. Factors which lower the present value estimate are those that decrease the numerator and increase the denominator of the equation. Thus, factors that decrease the estimates of annual

\footnotetext{
- Maisel, Land Costs for Single-Family Housing, in Catrfornia Housing Studies I, 56 (Center for Planning and Development Research, University of California at Berkeley, rg63).

${ }^{\circ} \mathrm{J}$. Lessinger, supra note $\mathrm{I}$, at $22 \mathrm{I}$.

${ }^{\top}$ K. B. Kenney, Pre-development Land Ownership Factors and Their Influence on Residential Development 3I (Research Memorandum submitted to Center for Urban and Regional Studies, Institute for Research in Social Science, University of North Carolina, Sept. 21, 1965).

${ }^{8}$ R. W. BAHL, A Biuegrass Leapfrog I8 (1963).

'J. E. Smith, supra note 2, at 47.
} 
pecuniary and nonpecuniary income, and/or increase the annual pecuniary and nonpecuniary expenses, and/or increase the transfer and transaction costs of selling the land, and/or decrease the estimated future value, and/or increase the rate of return on alternative investments would all tend to encourage the sale of the land by lowering the present value estimate.

In light of the landowner's investment calculus above and the three sets of factors (contextual, property, and landowner characteristics), there are at least three channels through which local governmental policy appears to affect the transition of land: (x) through influencing the landowner's annual income and expenses and thus the profitability of the investment; (2) through influencing the estimated future value of the land and thus the profitability of the investment; and (3) through influencing the present market value of the land relative to the landowner's estimated present value and thus affecting the decision to hold the land for investment or to sell.

Annual expenses are strongly influenced through local taxation policy; in fact, taxes on raw land may often represent the major cost in holding raw land as an investment. ${ }^{10}$ Smith found that the cost of taxes more often than not exceeds the current income, even though taxes as a percentage of the market value of the land may be minimal. In addition the impact of taxes is direct; each year the landowner must find the funds to meet this cost. The impact of local policy on income of the landowner is provided through the limitations placed by zoning on the economic use of the property. However, findings from Smith's study suggest that current income considerations are usually not as important as expenses in the landowner's calculus.

The impact of local policy on the estimated future value of the land, however, is less direct than its influence on current income and expenses. The certainty and availability of knowledge of future governmental actions related to spatial extension of public investment, such as highways, water and sewer system, and schools, can have an important stabilizing effect on estimates of future value. Zoning, if stable, can influence estimated future value by its limitation on potential use of the property. But the future value depends on so many other factors that the influence of policy is limited.

Under any given set of contextual and property characteristics influenced by public policy, the characteristics of the owner appear to be important in influencing the transition of a unit of land to urban residential use. There is empirical evidence to support the model's implication that if the landowner has major nonpecuniary motives for holding the land in addition to investment motives, he is less likely to sell simply because he is deriving more annual income from holding than he would be if he was not deriving satisfaction from those nonpecuniary motives. ${ }^{11}$ Furthermore, wealthy landowners tend to have high net worth and high liquidity. Both of

\footnotetext{
${ }^{10}$ Id. at 104 .

${ }^{11}$ Id. at 99-roo (table 22).
} 
these facts encourage holding onto the land because of lower rate of return on alternative forms of investment for these people and because they run less risk by holding the less liquid asset of land than does an owner who does not have other liquid assets. ${ }^{12}$

The property characteristics will also be important influences on the transition of land. Annual income, especially from farming, is dependent upon physical property characteristics such as topography, ground cover, and soil conditions of the land and structural improvements. The better the land for deriving an annual income, the higher the present value of the property for the landowner and therefore the less likely he is to sell. It is also important to note that physical property characteristics are not easily influenced by local governmental policy. However, the present market price and expected future market value depend especially on those existing and expected locational characteristics, such as prestige level of the location, accessibility (school, employment, shopping, recreation activities), and institutional characteristics, such as zoning protection, availability of public services, and subdivision regulations, that might apply to the site. These are affected by present and future government facilities, services, and regulatory controls. If services are already available to the site, then the present market value may compare very well with the future expected market value, and given that the latter would have to be discounted over time this would encourage earlier completion of the transition to urban residential use.

But the effectiveness of policy as an influence upon the transition of land to urban use will depend very much on other contextual, property, and decision agent characteristics. For example, the effectiveness of tax policy will depend on the contextual variable of the general rate of land value appreciation in the area, the spatial distribution of the decision agent characteristic of income, and importance of nonpecuniary motives for holding land among the landowners. "In areas with very rapid rates of appreciation, say on the order of 20 percent, only very heavy taxes on land would eliminate the investment potential" of holding land. ${ }^{13}$ Second, the impact of heavy taxes is less on wealthy landowners because the rate of return on alternative investments is less. Third, the impact will be less on landowners who have significant nonpecuniary motives for holding the land in addition to their pecuniary motives because this intangible current income increases the present value to the landowner but does not affect market value.

In this section we have discussed the major decision agent in the area of urban interest, i.e., the area of transition. 'The factors influencing a landowner's decision are similar whether the potential buyer is a developer who is actively considering it for residential development or a speculator who intends to hold the land for future appreciation of its value. Therefore, whether or not the land advances to the next state-that of actively being considered for development-depends then not only on

\footnotetext{
${ }^{12}$ Id. at $74-78$.

${ }^{13} \mathrm{Id}$. at $\mathrm{x} \mathrm{i6}$.
} 
the intention of the landowner to sell but most importantly on the buyer's evaluation of the property specifically as an input into the residential development process. Let us therefore move to the middle stages of the residential development process and to the developer as the major decision maker.

\section{III}

\section{The Developer's Three-Stage Locational, Decision: to Consider Land, to Purchase Land, and to Develop LaNd for Residential Use}

The three decisions to be discussed in this section carry the land from the state of urban interest to the state of being physically developed for residential use, state four in figure $\mathrm{r}$. They will be considered as related subdecisions in one overall locational decision made by what we consider to be the key decision maker in these middle stages of land transition-the residential developer.

In general, a site may pass from the state of urban interest to the state of active consideration for residential development when any one of several agents assumes initiative to contact other agents regarding the possible sale of a tract of land for residential purposes and not merely for further holding in anticipation of capital gain. The developer becomes the key decision maker because basically it is he who must insert the intention to develop the land as a means of profit rather than relying on land value appreciation for capital gain. If the developer feels that a tract may generally fill the specifications for the market he is seeking to meet or that there exists a potential demand for housing appropriate to a specific site called to his attention, and if he can obtain a tentative agreement from the landowner to sell, he then proceeds to the next decision stage in his locational decision process-the land purchase decision. It represents an entrepreneurial locational commitment in the technical production process for manufacturing the new residential housing supply. When the developer decides to purchase a site, he generally is making a commitment not only to an investment in the land but also to the much broader investment in a particular residential development which is to be produced on the site. The land purchase decision is crucial in the spatial pattern of conversion of the land to urban housing. The prior decision to consider the land is anticipatory to this decision; the latter decision to develop the land is anticlimatic to this decision, for the experience in our study area suggests that development typically follows within less than five years and probably in a form not much different than the development programmed at the time of the purchase. ${ }^{14}$ Once the land is purchased it is again the developer who is the principal agent in deciding the rate at which the property holdings are to be converted to completed residential packages.

Let us conceptualize a generalized locational decision to which we can relate

\footnotetext{
${ }^{14}$ S. F. Weis, J. E. Smith, E. J. Kaiser \& K. B. Kenney, Residential Developer Decisions: A Focused View of the Urban Growth Process 58 (Urban Studies Research Monograph, Center for Urban and Regional Studies, Institute for Research in Social Science, University of North Carolina, Ig66).
} 
local public policy and the aforementioned three sets of decision factors. The developer arrives at the locational decision by first reaching a very tentative decision to go ahead with development at a specific site subject to further investigation. In commencing this first stage of the three-stage location decision, the developer may follow one of two approaches. In what we call the marketing approach, the developer first identifies a demand for a specific price range of housing. After identifying certain crude site specifications for such housing, he then begins an active search for suitable land. In the other approach, which we call the contact approach, the developer's attention is called to the availability of a tract of land by another agent in the development process, such as a landowner, realtor, or lawyer acting as a broker for a landowner. Upon identifying a suitable housing product for the site, he may ascertain that a demand exists for that housing product. We have found in our empirical work that the generalized approach in the development industry consists of periodic searches superimposed upon random contacts made by other agents. ${ }^{15}$ Once the developer makes the tentative decision to go ahead, largely on intuition, he generally obtains a sixty- to ninety-day option, or in some other way comes to a temporary agreement with the landowner which will allow time for investigating the decision before fully committing himself to a purchase of the site.

This most important purchase decision stage actually involves a series of supporting studies and decisions regarding economic feasibility and risk. This stage requires numerous interactions with supporting decision participants in the development process, especially checks with financial intermediaries and public officials. The first order of business is often an economic feasibility study. This study evaluates the profitability of the proposed location in terms of its cost implications (the land engineering study) and its revenue implications (the marketability study). From a land engineering study the developer obtains a feasible plat of lots and street layout, required on-site and off-site improvements, and so on, which enable him to make an estimate of the average developed lot cost. To this estimate of developed lot cost (prorated cost of raw land and estimated physical development costs), he adds overhead costs and a "fair" profit. (Several developers mentioned the specific figure of twenty-five per cent as a desirable markup to cover overhead and fair profit.) In the marketability study, the developer determines, usually intuitively, whether or not there is sufficient demand in terms of annual sales volume for the price range of residential package (house, lot, and location) under consideration. The average lot value is a major output of the marketability study. At this point the developer compares estimated costs and revenues; he compares the minimum acceptable lot value (cost to the developer) to the estimated average lot value (revenue to the developer) to determine the profitability of the site.

This economic feasibility test is tempered by a consideration of investment risks. Some of the more important risks suggested in the interviews are:

${ }^{10}$ Id. at 3 I. 
I. Risks associated with the calculation of marketability. A striking characteristic of development entrepreneurship is the unsystematic approach to analysis of marketability. The fact component of this analysis is weak. This appears especially true of the controlling facts-those concerning the estimates of the level of market demand, the proper composition of the residential package components of house, lot, physical neighborhood, and location to meet consumer preferences in that market and alternative site availability. ${ }^{\mathbf{1 0}}$

2. Risks associated with land inventory-one risk is not being able to find suitable land when needed. A two- or three-year inventory in each market sector engaged in by the developer was considered reasonable by our sample, while a one-year inventory is minimum. The time is a function of the lag time between land purchase and the finished product being ready for the market. The smaller the inventory the more susceptible the developer is to purchase more marginal sites because of the risk of being without a product to sell at a future date.

If the land is to be held beyond the time it takes to develop the residential product on the land, then the developer must devote more consideration to the risks of changes in the price of the land and changes in consumer preferences or demand in the market for which the land is being evaluated. In our own empirical work we found that longer term land holding was not common practice. Most developers purchased land for a short-term inventory of suitable land to meet specific markets rather than for long-term speculation in appreciation of land values.

3. Risks associated with local public actions-the "if and when" risks of tax reassessment, annexation, installation of public capital improvements, such as schools, water and sewerage facilities, and highways. Changes in requirements imposed by health, subdivision, and zoning regulations, and so on, are all critical enough to affect profitability for the investment. Several developers in our sample were hurt by these risks. One did not get his land into a school district after he had counted on this. Another was left holding a number of lots unsuitable for septic tanks after the County Health Department stiffened its regulations.

4. Risks associated with obtaining necessary supporting decisions from financial intermediaries. These are critical in the developer's ability to complete the proposed development.

${ }^{10}$ This unsystematic approach to decisions by development entreprencurs appears to be a definite characteristic of the industry. In addition to our interviews, see Wheaton, Public and Private Agents of Change in Urban Expansion, in M. WEBber and Others, Explorations Into Urban Structure I68 (1964); Twin Cities Metropolitan Planning Comm'n, Sezected Determinants of Residential Development 3 (Background Document No. I, Series on Determinants of Urban Development, St. Paul, Minn., I962). 
In considering these above risks, it is only reasonable for the developer to attempt to reduce them. In fact, a substantial portion of the developer's entrepreneurial activity and strategy while holding an option is to ascertain and reduce these risks. He will make conservative decisions about the style of house, for example, to avoid risking disapproval of financial intermediaries. He will check his sources of permanent financing and insurers and guarantors of such financing (especially FHA and VA) for their tentative approval of the site and the residential package, but primarily at this time their approval of the price range of the residential package and the lot value. He will also check with public officials about subdivision regulations, zoning changes, school district boundary changes, scheduled public improvements to the site, and so on. And there are numerous other checks to be made in order to line up the affirmative locational decision. ${ }^{17}$

Let us examine the developer's locational decision sequence in the light of the analytical framework shown in figure 2. Again we are hypothesizing that the factors which influence the locational choice are contextual, property, and developer characteristics, and, indirectly, local public policy channeled through these sets of factors.

Again, the influence of local public policy on the residential developer's decision process is channeled primarily through the set of contextual factors and the set of property characteristics. But just as in the other residential decisions, the decision maker's characteristics will affect the reaction of the developer to the other two sets of factors. On the basis of our interviews and our conceptualizations of the decision process, we hypothesize that an influence can be analyzed by examining its effect on the expected costs, the expected revenues, or the risk of the investment.

The effect of contextual, property, and developer characteristics on marketability and revenue tend to dominate costs considerations in our study. If this is true generally, local public policy affecting revenues would tend to have more leverage than policy affecting costs. Property characteristics are key for they provide most of the basis on which the developer estimates costs and marketability of the proposed development. Our interviews indicated the estimated effects of property characteristics on marketability of the residential product far outweigh the estimated effects on cost of producing the product. One reason may be that cost implications for various sites were not quite as uncertain to the developer, nor did they tend to vary as much as marketability effects. In general, the higher the price range, the more important are the estimated marketability effects of the site characteristics as opposed to cost considerations.

Of the property characteristics affecting marketability, locational characteristics are clearly the most important. The frequency of the reply "location, location, location" (to the question about the most important factor in the land purchase decision)

\footnotetext{
${ }^{17}$ For a more detailed list of these checks and studies, see Wheaton, supra note 16 , at 154-96.
} 
supports this conclusion. And social prestige level of the location is clearly the most important aspect of the locational characteristics. Local public policy may have a substantial effect over a period of time on the accessibility of the site directly through governmental investment policies concerning transportation improvements, school and recreation facilities, and indirectly through zoning for shopping and employment activities. Physical characteristics, such as rolling topography and trees, also influence the amenity value of a site. Institutional characteristics, the most direct reflections of local policy, have some marketability effects. Our study shows that school district lines that tend to reflect differential standards, availability of urban services, and zoning protection appear significant, particularly in higher priced markets.

Despite the greater importance of the estimated marketability effects of site characteristics in our study area, the developer cannot afford to concentrate on marketability at any cost. The locational decision still requires weighing of the costs and thus it is possible for public policy to influence locational decisions by influencing the spatial pattern of land and physical development costs. Again property characteristics can be important, this time in two ways: First, topography, soil conditions, and zoning influence the number of lots derivable from a tract. Second, topography, soil characteristics, subdivision regulations, and zoning influence the costs of providing streets, utilities, and even building construction.

With regard to property characteristics, we have found in our empirical study that subdivision developers have stronger tendencies to locate where water and sewer are available, contiguous to existing development; and more moderate tendencies to locate where zoning protection exists, and where there is higher accessibility to employment areas and where socioeconomic prestige level of the site is higher. The physical characteristics of topography and soil conditions and the accessibility to central business district and schools and nearest major highway do not seem to be as important. ${ }^{18}$ Of course, this reflects only one study area with a special set of contextual characteristics which could cause behavior different than would be expected in general or observed in other specific urban areas.

As a contextual factor, public policy can also be a significant variable. It can affect the amount of influence of property characteristics by limiting the general quantity and spatial pattern of urban sites with certain site characteristics, particularly the institutional ones; it can create or remove scarcity of particular property characteristics. For example, it determines the quantity and spatial distribution of the supply of land zoned for a certain minimum lot size. Policy factors may also affect the cost function of the developer directly by establishing a maximum cost for certain production processes. For example, the Greensboro study area has a policy

\footnotetext{
${ }^{18}$ For a detailed analysis leading to this conclusion, see Kaiser, Location Decision Factors in a Producer Model of Residential Development, a paper presented at the Regional Science Ass'n mecting, Philadelphia, Pa., Nov. 12-14, 1965 (revised and expanded, August 1966).
} 
establishing a maximum charge on installation of streets, water, and sanitary sewer within the city limits. This reduced the effective development cost of sites within the city limits which had difficult topographic and soil conditions. It also added a degree of certainty to the developer's estimates of production costs. Thus, by determining the distribution of decision agent characteristics and site characteristics and by helping to set the general atmosphere of the community, the contextual factors can determine the amount of influence of individual decision agent characteristics and site characteristics upon the spatial pattern of locational decisions for urban residential development.

The developer characteristics, such as size of firm, entrepreneurial approach, and nature of the production process used, will affect the locational behavior under similar property and contextual factors. The attitude toward risk aspects of the entrepreneurial approach, and the amount of prefabrication, efficiency in use of equipment, skill in coordinating subdecisions of supporting decision agents will affect the relative attraction of different kinds of sites. In our empirical tests we have found significant differences between the locational decisions of large scale developers (those developing over roo lots per year) and the locational behavior of smaller scale developers. Large scale developers appear much more sensitive than smaller scale developers to accessibility, to availability of water and sewer, and to zoning protection at all price levels of subdivisions. ${ }^{19}$ Since these property characteristics reflect local policy, the findings suggest that policy makers should take into account the proportion of locational decisions made by different types of developers.

\section{IV}

\section{The Household's Decision to Purchase or Rent}

To this point the unit of property under discussion was the entire development project or at least sections of subdivisions which were developed as units in specified periods of time. Upon development into residential packages, the unit of property becomes that which can be associated with an individual dwelling unit. In the case of single-family homes the site is the lot. In the case of multifamily structures, the site becomes whatever private grounds can be associated with each dwelling unit (e.g., garden apartments) plus whatever grounds several dwelling units share in common that is not public property.

This is a significant change in focus. One obvious difference is in the impact of each individual decision, which is now reduced to smaller parcels of urban space. The number of decision makers increases many times and each one's decision has a smaller impact on the total, although in the aggregate this step in the chain of decisions is extremely important. This step determines the nature of the population which will reside in a sector of the community's space. This step, by implication, determines the nature and quantity of demand upon urban services; it establishes linkages, par-

\footnotetext{
${ }^{10} 1 d$.
} 
ticularly movement linkages to other spatial, social, and economic sectors of the community. When aggregated, the household locational decisions determine the character of neighborhoods, their viability, and ultimately their renewability and the movement patterns in the urban area.

Let us examine the consumer household's decision as a part of the residential mobility process. The household moves from a former residence to the selected residence in an attempt to fulfill more adequately basic shelter and accessibility needs and to satisfy certain desires with respect to living qualities and social mobility, yet staying within the constraints of a housing budget.

The household's characteristics which appear to be important influences upon residential mobility behavior are categorized into demographic and attitudinal characteristics and previous residential experience. ${ }^{20}$ The demographic characteristics of household size, place of work, stage in the family life cycle, and activity pattern determine household preferences for space, facilities, and accessibility in the residential package. The attitudinal characteristics of social mobility aspirations, actual mobility, and life style will determine the livability and prestige preferences governing the selection of a residential place. Household income, of course, is the single biggest factor in the residential budget, but aspirations, stage in the family life cycle, and household size also shape the housing budget to a greater or lesser extent.

The list of property characteristics considered by the predevelopment landowner and developer referred to the land. We must add the characteristics of the capital improvements produced in the development process, for these now become very important in the future transition of the property. Thus, instead of site characteristics we must, at this stage of the chain of events, consider all the characteristics of the residential package consisting of not only the original physical, locational, and institutional characteristics of the site as modified by the developer but also ( $\mathrm{I}$ ) the dwelling unit and other on-site improvements and (2) the social and physical neighborhood created by the development process and the types of households selecting residential packages nearby. The original site characteristics as modified by the developer, and the dwelling unit and other on-site improvements added in the production process, and the neighborhood around the site are inseparable; they are combined into an indivisible package which the household must select on a "take it or leave it" basis. The important characteristics with regard to the dwelling unit include: space, design, tenure (i.e., whether a rental or purchase dwelling unit), equipment, state of repair (if a used unit), or quality of construction (if either new or used unit). The most important characteristics with regard to the site are the locational as they imply: (I) an accessibility to the activity places which the household wishes to utilize, such as school, work place, shopping facilities, and doctor, and (2) a socioeconomic prestige level of the immediate neighborhood.

\footnotetext{
${ }^{\circ 0}$ Weiss, Kenney \& Steffens, Consumer Preferences in Residential Location: A Preliminary Investigation of the Home Purchaser Decision, Research Previews, April I966, at $x$.
} 
A number of studies have been done both at the Center and elsewhere which suggest relationships between household characteristics and characteristics of the residential package. ${ }^{21}$ Residential experience affects the household's preferences and selection. Previous owners who have lived in the area for a while place emphasis on the social location. ${ }^{22}$ This is especially true for families of higher income. Previous renters and households who have not lived long in the area tend to sacrifice both social location and accessibility in favor of "more space for the money."23 Since nonrooted households tend to maximize cost considerations, they will generally locate in the newer, large-tract subdivisions which are primarily on the outskirts of the urban or metropolitan area. This suggests that fringe areas and large-tract developments play an increasingly important role as reception areas for middle- and upper-income newcomers to the metropolitan area. ${ }^{24}$

Relating local governmental policies to household decisions, we feel that in a private market economy the influence is not easily incorporated into a model. Exceptions are open housing laws which discourage private market discrimination practices and therefore remove constraints which affect the household's locational choice. The limited public intervention indicates that governmental influence over the spatial structure of housing accommodations and populations either will have to be (I) indirectly applied by influencing the developer's choice of residential products to be produced in various locations or (2) applied more directly by influencing the course of change in the residential properties once developed and in this way influencing the future housing characteristics of an area.

As an indirect influence, the effect of policy on landowners and developers can be significant because their decisions precede those of the household in the resi-

\footnotetext{
${ }^{21}$ Reference should be made to the rich literature on residential consumer preferences and residential mobility for the multiplicity of household characteristics (needs, wants, and constraints) which infuence the choice of residential location and individual dwelling accommodations. Important references include, among others, Bell, Social Choice, Life Styles, and Suburban Residence, in The Suburban Community 225 (M. Dobriner ed. 1958); Foley, Wurster \& Smith, Housing Trends and Related Problems, in CaLIForNIA Housing Studies, supra note 5, at 57; N. Foote, J. Abu-Lughod, M. M. Foley \& L. Winnick, Housing Choices and Constranists (ig60); W. G. Grigsby, Housing Markets and Public Policy (ig63); M. Mexerson, B. Terretr \& W. L. C. Wheaton, Housing, People and Cities (1962); P. H. Rossi, Why Fanilies Move (1955); L. F. Schnore, The Urban Scene, especially pe 4, The Socioeconomic Status of Cities and Suburbs 20I-4I (1965); and Wilson, Livability of the City: Attitudes and Urban Development, in Urban Growth Dynamics ch. ix (F. S. Chapin, Jr. \& S. F. Weiss eds. Ig62).

For a series of related studies and follow up, see J. B. LANsing, REsidential Location and URBan Mobility: The Second Wave of Interviews (Survey Research Center, Institute for Social Research, University of Michigan, 1966); J. B. Lansing \& N. Barth, Residential Location and Urban Mobility: A Multivarinte ANalysis (Survey Research Center, Institute for Social Research, University of Michigan, 1966); Mueller, Consumer Aspirations and Housing Demand in the 1960's, in The Outloox on ConSUMER BEHAVTOR 47 (C. Lininger ed. Ig64).

${ }^{20}$ L. E. Arminger, Jr., Toward a Model of the Residential Location Decision: A Study of Recent and Prospective Buyers of New and Used Homes, I966, at 29 (unpublished thesis in University of North Carolina Library).

${ }^{23}$ Id. at 98 .

${ }^{24}$ Id. at 98-99. See also Governor's Advisory Comin'n on Housing Problems, Appendix to the Report on Housing in California 97 ( 1963 ).
} 
dential process. The developer determined the supply of new residential packages and made the decisions about on-site and off-site improvements added to the original site characteristics of the property. Especially important were the developer's decisions about the characteristics of the dwelling unit itself, because much of the consumer's housing choice appears to be based on the dwelling unit itself as opposed to the neighborhood and local portion of the residential package. ${ }^{25}$

As a more direct influence, local public policy can affect the course of change in a developed neighborhood through its level of services to the neighborhood, its housing and health codes, and zoning changes in the vicinity. By providing services, protecting the area from incongruous uses and discouraging neglect of the physical improvements, the local government encourages the maintenance of a residential area while opposite policies will encourage deterioration of the physical plant and possible change in the neighborhood composition. But much of the potential for maintenance or deterioration was incorporated in the quality of construction and planning of the original development; and much of the force for change or maintenance is beyond the local public policy in the socioeconomic context of the community which governs the economic vitality of the area, the residential and population trends, federal policy regarding financing for used and new housing, and so on.

More needs to be known about the leverage of local governmental policy to decide whether there is enough flexibility to warrant a strategy of attempting substantial control of residential change after initial development or whether the more appropriate strategy is to adapt governmental policy regarding service levels and so on to the externally controlled change.

\section{V}

\section{Implications for Future Policy}

The sequence of decisions in the residential development process illustrates the complex interdependent chain-like nature of the process of urban residential change. Our conceptualizations and empirical work thus far suggest that the design of public policy to influence this change must recognize the variety of decisions and decision makers to be involved in the process, the necessity to think in terms of influencing a chain of decisions rather than any single decision or decision maker, and the direct and indirect channels of influence through which local governmental influence can be brought to bear on the process.

For example, the conceptualizations suggest that a taxation policy may encourage some types of landowners to sell but not others, depending upon their wealth and personal motives for holding the land. And a policy that encourages selling may not necessarily lead to urban residential use of the land rather than further speculation unless the site is also profitable for investment in residential development. The

\footnotetext{
${ }^{25}$ N. Foote, J. ABu-Lughod, M. M. Foley \& L. Winnick, supra note 21, at 156, 183; and P. H. Rossi, supra note $2 \mathrm{I}$, at $\mathrm{I54}$.
} 
conceptualizations and empirical findings suggest that for landowners policies that affect expenses have more leverage than policies affecting current income. The reverse is true for the developers-that is, policies that affect revenues appear more critical to the locational decision of the developer than those which affect costs of development. Our research also gives evidence that decision agent characteristics are significant; for example, large scale developers' locational response to a policy was found to be significantly different from that of smaller developers.

In sum, the research seems to suggest that mixes of policies, rather than single policies, must be designed and/or evaluated-some of which are aimed at landowners, some at developers, and some at consumer households in already built-in areas. It also suggests that the success of a policy mix in any one sector of the urban region will depend upon the other noncontrollable physical, locational, and institutional property characteristics of the area, socioeconomic interaction, and the community's ad hoc policy course of action. Finally, the effect of a policy mix will also depend upon the characteristics of the key decision agents involved in the residential process - on whom we have focused in this article, and over whom very little direct control is currently, or is likely to be, available. A major aspect of the residential process to which local governmental policy must adapt is the landownerdeveloper-consumer chain of decision agents who operate in the private market economy. 